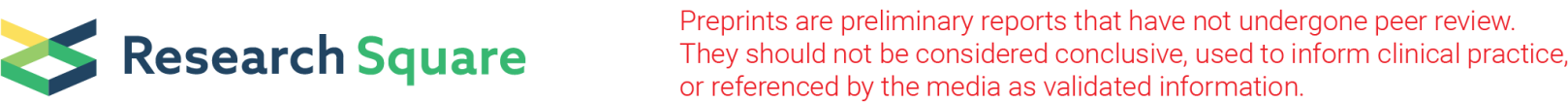

\section{Atrazine induced toxic impacts on the survival, behavior, and biochemical aspects of Silver carp (Hypophthalmichthys molitrix)}

Naireen Nayab

Kohat University of Science and Technology

Syed Ata Ur Rahman Shah ( $\square$ Shah.zoologist95@gmail.com )

Kohat University of Science and Technology https://orcid.org/0000-0002-7361-1043

Sana Ullah

University of Education

Muhammad Rauf

Kohat University of Science and Technology

Shandana Ali

Kohat University of Science and Technology

Shahid Niaz Khan

Kohat University of Science and Technology

Azizullah Azizullah

Kohat University of Science and Technology

Farman Ullah Dawar

Kohat University of Science and Technology

\section{Research Article}

Keywords: Atrazine, Acute toxicity, Hypophthalmichthys molitrix, Behavioral changes, Antioxidant enzymes

Posted Date: April 12th, 2021

DOI: https://doi.org/10.21203/rs.3.rs-374096/v1

License: (c) (1) This work is licensed under a Creative Commons Attribution 4.0 International License. Read Full License 


\section{Abstract}

The current research work was conducted to evaluate the acute toxicity of the widely used herbicide, Atrazine on the behavioral responses and biochemical changes in different tissues of Silver carp (Hypophthalmichthys molitrix). Adult fish were exposed to different concentrations of Atrazine for different time periods. Mortality of fish was observed with increase in the concentration of Atrazine and time of exposure. The $\mathrm{LC}_{50}$ of Atrazine for 96 hours was calculated as $13.7 \mu \mathrm{l} / \mathrm{L}$. Fish exposed to Atrazine showed fast swimming, loss of equilibrium and balance, gulping, pale body coloration, and an excess amount of mucous secretion covered the buccal cavity and gills. Total protein contents, antioxidant enzymes including catalase (CAT), peroxidase (POD), and glutathione reductase (GR) and lipid peroxidation (LPO), were measured in the brain, gills, liver, and muscle tissues for biochemical analysis. Atrazine exposure resulted in a significant time-dependent decrease in total protein content in the liver, gills, brain, and muscle tissue of fish compared to the control group. A slight increase was observed in the activities of CAT and POD in the control group, while a significant decrease was observed in the ATZtreated groups from 24 to $96 \mathrm{~h}$. The glutathione reductase activity was significantly increased in the ATZ treated groups compared to control group. Likely, LPO level also increased in the liver, gills, brain, and muscle tissue in a time-dependent and concentration-dependent manner in ATZ treated groups compared to control group. Concludingly, our results revealed that Atrazine is toxic to fish, alter enzymes and total protein level, and lipid peroxidation level in fish. This harmful effect of Atrazine maybe generalized into environment and reduce the Silver carp population in the natural freshwater bodies.

\section{Introduction}

Atrazine is a triazine herbicide that is widely used as a preemergence and postemergence herbicide for the control of weeds in maize, sorghum, pineapple, sugar cane and cereals (Singh et al. 2008; Singh et al. 2011). It is the second most widely consumed pesticide in the world with an annual consumption of about 70,000-90,000 tons (Kumar et al. 2013; Cheng et al. 2016). ATZ has been recorded in a concentration as high as $30 \mu \mathrm{g} / \mathrm{L}$ from ground and surface water (Singh et al. 2018). An estimated 2 to 3 million people, who use groundwater as their primary source of drinking water, are exposed to at least $0.2 \mathrm{ppb}$ of atrazine (US EPA 2001). Due to its persistence and frequent occurrence in groundwater above the permissible limits, ATZ has been banned in several developed countries (Huang et al. 2009; Bahlova et al. 2014; Glæsner et al. 2014; Vonberg et al. 2014), however, it is still commonly used in the world (Singh et al. 2018).

ATZ is thought to be a potential contaminant in aquatic habitats, where it may gain entry through run-offs from treated fields, spillage, or accidental discharge, as well as frequent torrential rains. Hence, ATZ residues are found in many environments, especially in surface- and ground-waters (Wightwick and Allinson 2007) whereas several studies reported ATZ from aquatic bodies above permissible limits by local guidelines (Davis et al. 2007). Atrazine is slowly degraded in the environment and its half-life may vary between 13 and 260 days (US EPA 2006). Thus, the indiscriminate use of ATZ herbicide to improve agricultural production has a devastating effect on non-targeted aquatic organisms including fish 
(Mhadhbi and Beiras 2012). Fish respond to contaminates similar to higher vertebrates therefore fish are used as an indicator in monitoring programs (Al-Sabti and Metcalfe 1995).

Studies showed changes induced by environmental pollutants on fish, such as long-term exposure to pesticides induces physiological disturbance, behavioral changes, histopathological damages, hematological alterations, biochemical changes, immune suppression, hormone disruption, reproductive abnormalities, cancer, and toxicities at the molecular level such as DNA damage and mRNA transcription (Pandey et al. 1995; Ullah and Zorriehzahra. 2015; Ullah et al. 2018; Ullah et al. 2019a). These adverse impacts are not only posed on fish but ATZ also leads to different types and level of toxicities in other animal models including mice (Zhang et al. 2011; Gely-Pernot et al. 2017), rats (Song et al. 2014; Abarikwu and Farombi 2016), tadpoles (frog) (Dornelles and Oliveira 2014), quail (Hussain et al. 2011), etc.

Atrazine adversely affecting the immune system of juvenile rainbow trout (Shelley et al. 2012) and common carp (Khalil et al. 2017). Atrazine has a profound effect on the oxidative stress markers and detoxifying enzyme of the exposed zebrafish (Blahová et al. 2013). Atrazine behaves as an enzyme inhibitor, impairing hepatic metabolism, and produces genotoxic damage to different cell types as studied in Plotosus lineatus (Santos and Martinez 2012). A lower concentration ( $1 \mu \mathrm{g} / \mathrm{L}$ ) of ATZ altered the endocrine function in Salmo salar (Moore and Lower 2001). The AChE mRNA transcription was significantly reduced in common carp after 40 days exposure to ATZ (Xing et al. 2010). The sublethal concentration of ATZ exposure led to a significant reduction in the bactericidal activities and phagocytic index of the serum, total serum peroxidase, and serum lysozyme in Rhmadia quelen (Kreutz et al. 2012). Exposure to ATZ showed histopathological damage and changes in the activities of antioxidant enzymes in the brain and kidney of common carp (Xing et al. 2012). Exposure of Cyprinus carpio to different concentration of ATZ led to disturbed biochemical profile (Blahova et al. 2014). A significant decrease in the RBCs, hematocrit, and hemoglobin was observed in Tor grypus after exposure to ATZ (Zadeh et al. 2016).

Silver carp is an economically important fish species because of its huge annual yield and high nutritional value (Li et al. 2011). Silver carp along with bighead carp accounted for more than 6.5 million tons and over $19.3 \%$ of the total freshwater fish production around the world (FAO 2012). This global economic importance of silver carp compelled us for studying its response against a highly employed pesticide across the globe. Although the toxicities of ATZ-based herbicides have been widely studied in diverse groups of aquatic organisms, studies concerning the impacts of ATZ on Silver carp are still rare. Thus, this study aims to determine the acute toxicity of ATZ on the behavior and biochemical responses in different tissues of Silver carp.

\section{Materials And Methods}

\subsection{Collection and acclimatization of fish}


Silver carp $(23.3 \pm 1.4 \mathrm{~g}, 15.2 \pm 0.70 \mathrm{~cm})$ were obtained from a local fish hatchery and carried to the Laboratory of Fisheries and Aquaculture, Department of Zoology, Kohat University of Science and Technology, Kohat. The fish were acclimatized one week before the start of the experiments. All fish were cautiously examined and treated with $0.2 \% \mathrm{KMnO}_{4}$ solution for two minutes before stocking to prevent any dermal infection (Khan et al. 2016). The $\mathrm{pH}$ and water temperature in the tanks were kept constant and checked every other day $\left(\mathrm{pH}: 7.2\right.$, Temperature $21^{\circ} \mathrm{C}$, dissolved oxygen: $6-7 \mathrm{mg} / \mathrm{L}$, Conductivity 750 $\mu \mathrm{S} / \mathrm{cm}$, total dissolved solid: $370 \mathrm{mg} / \mathrm{L}$ )

\subsection{ATZ dilution}

Technical grade ATZ (97.5\%) (Sigma Chemical, USA) was used for experiments. By dissolving $5 \mathrm{ml}$ of ATZ in $5 \mathrm{ml}$ of 80 percent acetone, a stock solution was prepared. From this stock solution, $1 \mathrm{ml}$ was dissolved in $9 \mathrm{ml}$ distilled water and this solution was used for making test concentrations (Dawar et al. 2016).

\subsection{Acute Toxicity Experiment}

One group was formed as the control group consists of 05 fish and kept without treatment. For acute toxicity analysis, 20 fish were taken and four treatment groups were made and concentrations were applied through water flow system. Groups 1 and 2, consisting of 05 fish each, were treated under a dose of $08 \mu \mathrm{l} / \mathrm{L}$ and $10 \mu \mathrm{l} / \mathrm{L}$ for $24,48,72$, and 96 hours, respectively. Groups 3 and 4, consisting each of 05 fish, were processed under a dose of $13 \mu \mathrm{l} / \mathrm{L}$ and $15 \mu \mathrm{l} / \mathrm{L}$ up to 96 hours, respectively. After 24, 48, 72, and $96 \mathrm{~h}$, the number of dead and live specimens was noted and the $\mathrm{LC}_{50}(96 \mathrm{~h})$ was calculated using the protocol of Kumar et al. (2007).

\subsection{Behavioral study}

The behavior of fish from both groups was examined by noticing their breathing, movement, balance, air gulping, and operculum beating. The body color of the fish was also observed.

\subsection{Fish Dissection}

After exposure to different concentrations of Atrazine in the tanks, fish were collected and dissected from both control and treatment groups and different organs including liver, brain, gills, and muscle tissue were extracted out. To anesthetize the collected specimens, MS 222 was used.

\subsection{Biochemical study}

Total protein content, lipid peroxidation level, and antioxidant enzymes (catalase, peroxidase, and glutathione reductase) were assessed. For biochemical parameters, $10 \mathrm{mg}$ of preserved tissue was homogenized with an ultra-sonic machine of $25 \mathrm{mM} \mathrm{KH}_{2} \mathrm{PO}_{4}$ buffer containing $1 \mathrm{mM}$ EDTA and centrifuged at $4^{\circ} \mathrm{C}$ at $12000 \mathrm{rpm}$ for 15 minutes. For protein and antioxidant enzyme analysis, the supernatant was stored at $-80^{\circ} \mathrm{C}$, and the pellet was disposed of by following the protocol employed by Dawar et al. (2016). 


\subsubsection{Total protein estimation}

The total protein content in the liver, brain, gills, and muscle tissue was measured, using BSA as a standard, according to the Lowry method (Lowry et al. 1951).

\subsubsection{Catalase Assay}

Catalase activity was appraised by following Chance and Maehly (1955). The reaction mixture was prepared by adding $100 \mu \mathrm{l}$ of enzyme extract to $25 \mu \mathrm{l}$ of $10 \mathrm{mM} \mathrm{H}_{2} \mathrm{O}_{2}$ and $2.7 \mathrm{ml}$ potassium phosphate buffer. The final volume was made up to $3 \mathrm{ml}$ by the addition of distal water. Absorbance was measured at $240 \mathrm{~nm}$ after $1 \mathrm{~min}$ by using a spectrophotometer.

\subsubsection{Peroxidase Assay}

POD activity was calculated according to the process used by Chance and Maehly (1955). Briefly, $3 \mathrm{ml}$ reaction mixture was prepared by addition of $0.1 \mathrm{ml}$ enzyme extract, $0.1 \mathrm{ml}$ of $1.5 \%$ guaiacol, $2.7 \mathrm{ml}$ potassium phosphate buffer, and $0.1 \mathrm{ml}$ of $0.4 \% \mathrm{H}_{2} \mathrm{O}_{2}$. Then after $1 \mathrm{~min}$ absorbance of the reaction solution was measured at $470 \mathrm{~nm}$.

\subsubsection{Glutathione reductase (GR) Assay}

Glutathione reductase (GR) was measured by following Carlberg and Mannervik (1975) in the brain, gills, liver, and muscle tissue. Total $2 \mathrm{ml}$ of the reaction mixture was prepared which contained $0.1 \mathrm{ml}$ of enzyme extract, $1.65 \mathrm{ml}$ phosphate buffer, $0.1 \mathrm{ml}$ EDTA, $0.1 \mathrm{ml}$ NADPH and $50 \mu$ l oxidized glutathione $1 \mathrm{mM}$. The GR activity was evaluated by mixing the reaction mixtures and calculating the wavelength of NADPH disappearance at $25^{\circ} \mathrm{C}$ and $340 \mathrm{~nm}$.

\subsubsection{Lipid peroxidation assay}

LPO activity was performed according to the protocol of Wright et al. (1981). For different periods, the LPO estimation level in the liver brain, gills, and muscle tissue of both the control and ATZ-exposed fish was checked. The medium was prepared for the LPO evaluation by applying $100 \mu$ l of enzyme extract to the $250 \mu \mathrm{l}$ phosphate buffer, $100 \mu \mathrm{l}$ of ascorbic acid, and $10 \mu \mathrm{l}$ of ferric chloride. The whole mixture was put at $37^{\circ} \mathrm{C}$ for $1 \mathrm{~h}$ in a water bath. The reaction was stopped by adding $1 \mathrm{ml}$ of $10 \%$ trichloroacetic acid, 0.5 $\mathrm{ml}$ of $0.67 \%$ thiobarbituric acid to each tube, and was retained for 20 minutes in a boiling water bath. Upon cooling, the sample was centrifuged for $10 \mathrm{~min}$ at $4000 \mathrm{rpm}$. By using a spectrophotometer supernatant was collected and absorbance is measured at $532 \mathrm{~nm}$.

\section{Statistical analysis}

The obtained data was analyzed by one-way analysis of variance (ANOVA). A $p$-value smaller than 0.05 $(P<0.05)$ was considered statistically significant.

\section{Results}




\subsection{Behavioural and Morphological effects}

The observed behavioural responses of fish exposed to different concentrations of Atrazine for 96 hours are presented in Table 1. In the control group, the fish did not show any abnormal behavior.

\subsection{Acute toxicity}

Total mortality observed in various treated groups for 96 hours at each 24 hours interval of Atrazine exposure is shown in Table 2. An increase in mortality was observed with increasing concentrations of Atrazine herbicide. In the control group, no mortality was observed.

\section{3 $\mathrm{LC}_{50}$ Determination}

$\mathrm{LC}_{50}$ is the lethal concentration that kills $50 \%$ of the population. The 96 -hour LC50 value for Atrazine was 13.7 $\mu \mathrm{l} / \mathrm{L}$ was presented in Table 3.

Table 1

Behavioral responses of Silver carp exposed to different concentrations of Atrazine for 96 hours at $21^{\circ} \mathrm{C}$

\begin{tabular}{|lcccc|}
\hline Behavioral Responses & Control & \multicolumn{3}{l|}{ Atrazine Concentrations } \\
\cline { 2 - 5 } & $8(\mu \mathrm{l} / \mathrm{L})$ & $10(\mu \mathrm{l} / \mathrm{L})$ & $13(\mu \mathrm{l} / \mathrm{L})$ & $15(\mu \mathrm{l} / \mathrm{L})$ \\
\hline Fast swimming & & + & ++ & ++ \\
\hline Loss of equilibrium and balance & & + & ++ & ++ \\
Gulping & + & ++ & +++ \\
Pale body color & & + & ++ & +++ \\
\hline Excess amount of mucous secretion & & + & +++ & +++ \\
\hline
\end{tabular}

Key: -: Normal behavior, +: Low, ++: Moderate, +++: High

Table 2

Acute toxicity test of Atrazine exposed Silver carp during 96 hours at $21^{\circ} \mathrm{C}$.

\begin{tabular}{|c|c|c|c|c|c|c|c|}
\hline \multirow[t]{2}{*}{ Concentrations $(\mu \mathrm{l} / \mathrm{L})$} & \multirow[t]{2}{*}{ No of fish exposed/group } & \multicolumn{4}{|c|}{ Mortality (h) } & \multirow[t]{2}{*}{ \% survival } & \multirow[t]{2}{*}{$\%$ mortality } \\
\hline & & & 187 & 96 & & & \\
\hline $0 \mu \mathrm{l} / \mathrm{L}$ (control) & 5 & 0 & 0 & 0 & 0 & 100 & 0 \\
\hline $8 \mu \mathrm{l} / \mathrm{L}$ & 5 & 0 & 0 & 0 & 0 & 100 & 0 \\
\hline $10 \mu \mathrm{l} / \mathrm{L}$ & 5 & 0 & 0 & 0 & 0 & 100 & 0 \\
\hline $13 \mu \mathrm{l} / \mathrm{L}$ & 5 & 0 & 0 & 0 & 1 & 80 & 20 \\
\hline $15 \mu \mathrm{l} / \mathrm{L}$ & 5 & 0 & 1 & 1 & 1 & 40 & 60 \\
\hline
\end{tabular}


Table 3

Determination of Atrazine $\mathrm{LC}_{50}$ value in Silver carp for 96 hours at $21^{\circ} \mathrm{C}$.

\begin{tabular}{|llllll|}
\hline Concentration & $\begin{array}{l}\text { Concentration } \\
\text { difference }\end{array}$ & $\begin{array}{l}\text { No of fish } \\
\text { exposed per } \\
\text { group }\end{array}$ & $\begin{array}{l}\text { Number of } \\
\text { dead fish }\end{array}$ & $\begin{array}{l}\text { Mean } \\
\text { death }\end{array}$ & $\begin{array}{l}\text { Mean death } \times \\
\text { concentration } \\
\text { difference }\end{array}$ \\
\hline 0 (Control) & 0 & 5 & 0 & 0 & 0 \\
\hline $8 \mu \mathrm{l} / \mathrm{L}$ & 8 & 5 & 0 & 0 & 0 \\
\hline $10 \mu \mathrm{l} / \mathrm{L}$ & 2 & 5 & 0 & 0 & 0 \\
\hline $13 \mu \mathrm{l} / \mathrm{L}$ & 3 & 5 & 1 & 0.5 & 1.5 \\
\hline $15 \mu \mathrm{l} / \mathrm{L}$ & 2 & 5 & 3 & 2.5 & 5 \\
\hline & & & & & $\sum=6.5$ \\
\hline
\end{tabular}

The $\mathrm{LC}_{50}$ (Lethal concentration with $50 \%$ mortality) was calculated as:

$\mathrm{LC}_{50}=\mathrm{LC}_{100}-\sum$ (Mean death $\times$ concentration difference) $/$ Number of fish per group

$\mathrm{LC}_{50}=15-6.5 / 5=13.7 \mu \mathrm{l} / \mathrm{L}$

\subsection{Total protein estimation}

In the present study, total protein contents in the liver, gills, brain, and muscle of Silver carp exposed to varying concentrations of Atrazine for different periods has been significantly reduced as compared to the control groups shown in Figs. 1, 2, 3 and 4.

\subsection{Catalase Assay:}

In current work, the atrazine exposure causes a significant decrease in the activity of CAT in the liver, gills, brain, and muscle tissue exposed to ATZ 8, ATZ10, ATZ13, and ATZ15 for 24, 48, 72, and 96 hours. The Catalase activity increased significantly from 24 to $96 \mathrm{~h}$ in the control group whereas decreased in ATZ treated group Shown in Table 4.

\subsection{Peroxidase Assay}

In the present study, the POD activity was significantly decreased in the liver, gills, brain, and muscles tissue exposed to ATZ 8, ATZ10, ATZ13, and ATZ15 for 24, 48, 72, and 96 hours compared to the control group where it increases with the time shown in Table 5.

\subsection{Glutathione reductase assay}

In the current work Atrazine exposure cause a significant increase in the activity of GR in the liver, gills, brain, and muscles tissue exposed to a different experimental period of ATZ 8, ATZ10, ATZ13, and ATZ15 for $24,48,72$, and 96 hours as compared to the control group. Exposure of fish to Atrazine did not affect Glutathione reductase in gills (Table 6). 


\subsection{Effect of Atrazine on Lipid peroxidation}

The result of the present study revealed that the ATZ Administration resulted in an increase in MDA level in liver, gills, brain, and muscle of ATZ exposed groups compared to the control group (Figs. 5, 6, 7 and 8). 
Table 4

Activity of Catalase ( $\mu \mathrm{mol} / \mathrm{min} / \mathrm{mg} /$ protein) in the liver, gills, brain, and muscle of Silver carp exposed to different concentrations of Atrazine for 96 hours at $21^{\circ} \mathrm{C}$

\begin{tabular}{|c|c|c|c|c|c|}
\hline Exposure time & Groups & Liver & Gills & Brain & Muscle \\
\hline \multirow[t]{5}{*}{$24 \mathrm{~h}$} & CTR & $11 \pm 0.78^{a}$ & $5 \pm 0.48^{a}$ & $3 \pm 0.11^{a}$ & $3 \pm 0.28^{a}$ \\
\hline & ATZ 8 & $8 \pm 0.60^{\mathrm{ab}}$ & $5 \pm 09^{a b}$ & $2 \pm 0.15^{a}$ & $3 \pm 0.26^{a b}$ \\
\hline & ATZ 10 & $7 \pm 0.54^{a}$ & $5 \pm 0.31^{b}$ & $2 \pm 0.13^{\mathrm{ab}}$ & $2 \pm 0.49^{b}$ \\
\hline & ATZ 13 & $5 \pm 0.76^{a}$ & $6 \pm 0.70^{b}$ & $1 \pm 0.10^{b}$ & $4 \pm 0.65^{b}$ \\
\hline & ATZ 15 & $4 \pm 0.70^{b}$ & $3 \pm 0.58^{b}$ & $1 \pm 0.39^{a b}$ & $1 \pm 0.20^{b}$ \\
\hline \multirow[t]{5}{*}{$48 h$} & CTR & $11 \pm 0.56^{a}$ & $6 \pm 0.78^{a}$ & $3 \pm 0.20^{a}$ & $4 \pm 0.43^{a}$ \\
\hline & ATZ 8 & $9 \pm 0.55^{\mathrm{ab}}$ & $4 \pm 0.5^{b}$ & $3 \pm 0.90^{\mathrm{ab}}$ & $2 \pm 0.23^{b c}$ \\
\hline & ATZ 10 & $7 \pm 0.42^{\mathrm{ab}}$ & $2 \pm 0.64^{c}$ & $2 \pm 0.43^{b c}$ & $2 \pm 0.34^{c}$ \\
\hline & ATZ 13 & $6 \pm 0.48_{b}$ & $2 \pm 0.19^{c}$ & $1 \pm 0.32^{c}$ & $3 \pm 0.22^{b c}$ \\
\hline & ATZ 15 & $7 \pm 0.42^{b}$ & $2 \pm 0.36^{b}$ & $1 \pm 0.19^{\mathrm{ab}}$ & $1 \pm 0.51^{c}$ \\
\hline \multirow[t]{5}{*}{$72 \mathrm{~h}$} & CTR & $9 \pm 0.47^{a}$ & $6 \pm 0.51^{\mathrm{a}}$ & $2 \pm 0.8^{\mathrm{a}}$ & $4 \pm 0.24^{a}$ \\
\hline & ATZ 8 & $7 \pm 0.52^{b}$ & $5 \pm 0.33^{b}$ & $2 \pm 0.12^{c}$ & $3 \pm 0.48^{c}$ \\
\hline & ATZ 10 & $3 \pm 0.33^{\mathrm{ab}}$ & $2 \pm 0.28^{c}$ & $2 \pm 0.19^{c d}$ & $2 \pm 0.41^{c}$ \\
\hline & ATZ 13 & $2 \pm 0.58^{b}$ & $2 \pm 0.27^{c}$ & $3 \pm 0.32^{d}$ & $2 \pm 0.38^{c}$ \\
\hline & ATZ 15 & $2 \pm 0.62^{b}$ & $1 \pm 0.58^{c}$ & $1 \pm 0.03^{b}$ & $1 \pm 0.44^{\mathrm{cd}}$ \\
\hline \multirow[t]{5}{*}{$96 \mathrm{~h}$} & CTR & $12 \pm 0.68^{a}$ & $6 \pm 0.04^{a}$ & $3 \pm 0.18^{a}$ & $4 \pm 0.56^{\mathrm{a}}$ \\
\hline & ATZ 8 & $4 \pm 0.87^{b}$ & $3 \pm 0.45^{c}$ & $3 \pm 0.34^{d}$ & $2 \pm 0.07^{d}$ \\
\hline & ATZ 10 & $3 \pm 0.48^{b}$ & $3 \pm 0.34^{c}$ & $2 \pm 0.12^{d}$ & $1 \pm 0.06^{d}$ \\
\hline & ATZ 13 & $5 \pm 0.47^{b}$ & $2 \pm 0.11^{d}$ & $1 \pm 0.53^{e}$ & $1 \pm 0.15^{d}$ \\
\hline & ATZ 15 & $1 \pm 0.13^{b}$ & $1 \pm 0.91^{d}$ & $1 \pm 0.20^{b}$ & $1 \pm 0.12^{d}$ \\
\hline
\end{tabular}

CTR $=$ Control; $A T Z=$ Atrazine Exposed; Data are expressed as mean \pm S.E. Different letters indicate significant differences between the groups. 
Table 5

Activity Peroxidase (nmol/min/mg protein) in the liver, gills, brain, and muscle of Silver carp exposed to Atrazine for 96 hours at $21^{\circ} \mathrm{C}$

\begin{tabular}{|c|c|c|c|c|c|}
\hline Exposure time & Groups & Liver & Gills & Brain & Muscle \\
\hline \multirow[t]{5}{*}{$24 \mathrm{~h}$} & CTR & $19.7 \pm 0.81^{a}$ & $15.5 \pm 0.28^{a}$ & $19.4 \pm 0.07^{a}$ & $2.57 \pm 0.07^{a}$ \\
\hline & ATZ 8 & $15.1 \pm 0.76^{b}$ & $22.4 \pm 0.23^{b}$ & $16.1 \pm 0.09^{b}$ & $2.34 \pm 0.32^{\mathrm{ab}}$ \\
\hline & ATZ 10 & $14.7 \pm 0.10^{\mathrm{a}}$ & $13.5 \pm 0.31^{a}$ & $14.2 \pm 0.13^{b}$ & $2.18 \pm 0.13^{a}$ \\
\hline & ATZ 13 & $10.5 \pm 0.66^{b}$ & $11.3 \pm 0.22^{b}$ & $14.2 \pm 0.15^{b}$ & $1.56 \pm 0.21^{b}$ \\
\hline & ATZ 15 & $9.29 \pm 0.20^{b}$ & $15.2 \pm 0.01^{b}$ & $14.6 \pm 0.15^{b}$ & $0.92 \pm 0.00^{b}$ \\
\hline \multirow[t]{5}{*}{$48 h$} & CTR & $19.2 \pm 0.65^{a}$ & $13.4 \pm 0.18^{a}$ & $20.8 \pm 0.06^{a}$ & $2.77 \pm 0.10^{\mathrm{a}}$ \\
\hline & ATZ 8 & $20.0 \pm 0.75^{b}$ & $23.6 \pm 0.17^{b}$ & $14.6 \pm 0.19^{c}$ & $2.60 \pm 0.28^{b}$ \\
\hline & ATZ 10 & $18.0 \pm 0.48^{a}$ & $23.8 \pm 0.15^{b}$ & $11.5 \pm 0.24^{c}$ & $1.86 \pm 0.00^{b}$ \\
\hline & ATZ 13 & $11.6 \pm 0.20^{b}$ & $19.2 \pm 0.10^{c}$ & $15.6 \pm 0.22^{c}$ & $1.32 \pm 0.11^{\mathrm{c}}$ \\
\hline & ATZ 15 & $6.44 \pm 0.24^{b c}$ & $14.2 \pm 0.19^{c}$ & $10.2 \pm 0.07^{c}$ & $0.74 \pm 0.00^{b}$ \\
\hline \multirow[t]{5}{*}{$72 \mathrm{~h}$} & CTR & $21.5 \pm 0.92^{\mathrm{a}}$ & $16.7 \pm 0.25^{a}$ & $20.8 \pm 0.10^{a}$ & $3.33 \pm 0.19^{a}$ \\
\hline & ATZ 8 & $24.4 \pm 0.31^{c}$ & $21.5 \pm 0.10^{c}$ & $11.3 \pm 0.17^{d}$ & $2.39 \pm 0.12^{c}$ \\
\hline & ATZ 10 & $15.5 \pm 0.24^{\mathrm{ab}}$ & $18.7 \pm 0.12^{c}$ & $8.52 \pm 0.16^{d}$ & $1.81 \pm 0.22^{c}$ \\
\hline & ATZ 13 & $21.3 \pm 0.42^{c}$ & $25.4 \pm 0.10^{d}$ & $6.25 \pm 0.12^{d}$ & $0.09 \pm 0.00^{d}$ \\
\hline & ATZ 15 & $11.5 \pm 0.23^{b c}$ & $12.4 \pm 0.16^{d}$ & $5.39 \pm 0.07^{d}$ & $0.43 \pm 0.00^{c}$ \\
\hline \multirow[t]{5}{*}{$96 \mathrm{~h}$} & CTR & $30.1 \pm 0.15^{a}$ & $17.5 \pm 0.22^{\mathrm{a}}$ & $22.2 \pm 0.15^{a}$ & $3.46 \pm 0.38^{a}$ \\
\hline & ATZ 8 & $14.3 \pm 0.40^{d}$ & $24.4 \pm 0.10^{d}$ & $10.1 \pm 0.01^{d}$ & $1.77 \pm 0.09^{d}$ \\
\hline & ATZ 10 & $11.3 \pm 0.27^{b}$ & $21.7 \pm 0.05^{d}$ & $6.54 \pm 0.31^{e}$ & $1.58 \pm 0.07^{d}$ \\
\hline & ATZ 13 & $10.6 \pm 0.24^{d}$ & $12.5 \pm 0.21^{\mathrm{e}}$ & $4.56 \pm 0.05 \mathrm{e}$ & $0.03 \pm 0.00^{e}$ \\
\hline & ATZ 15 & $4.2 \pm 0.10^{c}$ & $10.6 \pm 0.17^{e}$ & $3.24 \pm 0.15^{\mathrm{e}}$ & $0.01 \pm 0.00^{c}$ \\
\hline
\end{tabular}

$\mathrm{CTR}=$ Control ATZ $=$ Atrazine Data are expressed as mean \pm S.E. Different letters indicate significant differences between the groups. 
Table 6

Activity of Glutathione reductase ( $\mathrm{nmol} / \mathrm{min} / \mathrm{mg}$ protein) in the liver, gills, brain, and muscle of Silver carp exposed to Atrazine for 96 - hour at $21^{\circ} \mathrm{C}$

\begin{tabular}{|c|c|c|c|c|}
\hline Exposure time & Groups & Liver & Brain & Muscle \\
\hline \multirow[t]{5}{*}{$24 \mathrm{~h}$} & CTR & $5.15 \pm 0.17^{a}$ & $15.1 \pm 0.56^{\mathrm{a}}$ & $3.53 \pm 0.13^{a}$ \\
\hline & ATZ 8 & $5.63 \pm 0.44^{a b}$ & $10.4 \pm 0.08^{b}$ & $3.25 \pm 0.15^{b}$ \\
\hline & ATZ 10 & $3.26 \pm 0.16^{b}$ & $7.4 \pm 0.16^{b}$ & $5.85 \pm 0.15^{b}$ \\
\hline & ATZ 13 & $4.43 \pm 0.09^{b}$ & $9.39 \pm 0.24^{b}$ & $5.36 \pm 0.22^{b}$ \\
\hline & ATZ 15 & $7.37 \pm 0.15^{\mathrm{b}}$ & $12.5 \pm 0.17^{b}$ & $4.58 \pm 0.17^{b}$ \\
\hline \multirow[t]{5}{*}{$48 \mathrm{~h}$} & CTR & $5.93 \pm 0.05^{\mathrm{a}}$ & $17.3 \pm 0.25^{\mathrm{a}}$ & $2.57 \pm 0.35^{a}$ \\
\hline & ATZ 8 & $6.40 \pm 0.13^{b}$ & $14.2 \pm 0.05^{c}$ & $2.13 \pm 0.05^{c}$ \\
\hline & ATZ 10 & $7.64 \pm 0.38^{c}$ & $15.1 \pm 0.16^{c}$ & $3.59 \pm 0.30^{c}$ \\
\hline & ATZ 13 & $11.2 \pm 0.07^{c}$ & $18.4 \pm 0.13^{c}$ & $5.48 \pm 0.29^{c}$ \\
\hline & ATZ 15 & $6.48 \pm 0.26^{c}$ & $20.2 \pm 0.22^{c}$ & $7.32 \pm 0.28^{c}$ \\
\hline \multirow[t]{5}{*}{$72 \mathrm{~h}$} & CTR & $5.48 \pm 0.16^{a}$ & $14.2 \pm 0.16^{\mathrm{a}}$ & $2.07 \pm 0.01^{a}$ \\
\hline & ATZ 8 & $4.65 \pm 0.12^{b c}$ & $11.3 \pm 0.15^{d}$ & $2.06 \pm 0.29^{d}$ \\
\hline & ATZ 10 & $4.94 \pm 0.05^{d}$ & $9.28 \pm 0.6^{d}$ & $2.18 \pm 0.28^{d}$ \\
\hline & ATZ 13 & $10.3 \pm 0.09^{d}$ & $16.5 \pm 0.19^{d}$ & $7.36 \pm 0.24^{d}$ \\
\hline & ATZ 15 & $14.4 \pm 0.18^{d}$ & $21.3 \pm 0.25^{d}$ & $7.52 \pm 0.34^{d}$ \\
\hline \multirow[t]{5}{*}{$96 \mathrm{~h}$} & CTR & $4.54 \pm 0.22^{\mathrm{a}}$ & $18.1 \pm 0.12^{\mathrm{a}}$ & $1.47 \pm 0.07^{a}$ \\
\hline & ATZ 8 & $9.36 \pm 0.12^{c}$ & $13.2 \pm 0.17^{e}$ & $2.41 \pm 0.31^{d}$ \\
\hline & ATZ 10 & $11.3 \pm 0.21^{\mathrm{e}}$ & $15.8 \pm 0.02^{\mathrm{e}}$ & $2.89 \pm 0.12^{d}$ \\
\hline & ATZ 13 & $8.58 \pm 0.16^{\mathrm{e}}$ & $22.2 \pm 0.10^{e}$ & $6.24 \pm 0.17^{d}$ \\
\hline & ATZ 15 & $15.3 \pm 0.26^{\mathrm{e}}$ & $23.3 \pm 0.02^{\mathrm{e}}$ & $6.70 \pm 0.12^{\mathrm{e}}$ \\
\hline
\end{tabular}

$\mathrm{CTR}=$ Control, $\mathrm{ATZ}=$ Atrazine. Data are expressed as mean \pm S.E. Different letters indicate significant differences between the groups.

\section{Discussion}


Atrazine herbicides are used for the prevention of broadleaf weeds in crops (Cui et al. 2002). The fact that, Atrazine is highly mobile and can move to untargeted areas especially aquatic bodies after application (Waring and Moore 2004), where different concentrations of atrazine showed different changes in fish biochemical parameters (Elia et al. 2002), compelled us to elucidate the acute toxicity of Atrazine on the freshwater fish. In this study, the effects of ATZ acute toxicity on Silver carp were measured during $24,48,72$, and 96 hours. The $L_{50}$ of ATZ for 96 hours was determined to be $13.7 \mu \mathrm{l} / \mathrm{L}$ for Silver carp, unlike Xing et al. (2015) found $2.142 \mathrm{mg} / \mathrm{L}$ of $A T Z$ to be $L_{50}$ for 96 hours against Common carp. The $\mathrm{LC}_{50}$ of ATZ against bluegill sunfish was found to be $16 \mathrm{mg} / \mathrm{L}$ (Tomlin 2000) and $9957 \mu \mathrm{l} / \mathrm{L}$ against Psetta maxima (Lazhar et al. 2012), and $24.95 \mathrm{ppm}$ against Rutilis frisii kutum (Khoshnood et al. 2014) for 96 hours. The LC $_{50}$ of ATZ for 24 hours against Cyprinus carpio was 18.5 ppm (Ramesh et al. 2009). The difference in the $L_{50}$ of the same toxicant is embodied to the test species (their age, size, health, antioxidant capacity, and immunity) and experimental conditions. The physicochemical parameters of the water including $\mathrm{DO}$, turbidity, $\mathrm{pH}$, temperature, and formulation of the chemical also contribute to these differences. Moreover, the toxicant can dissociate and transform to different sub-types/daughter chemicals, which might be less/more toxic, or having the same potential of toxicity as the parent chemical.

Fish exposed to atrazine showed behavioral defects such as rapid swimming, loss of balance, grouping, mucous on the body, and other irregular behavior. In the beginning, the fish were found to be healthy and very active. During the experiment, they sought to get rid of the water by swiftly swiping the tested water, jumping, and performing some other random movements for some time. There was no change observed in control/unexposed fish. Fish became pale as the intensity of body color decreased, which might be associated with the increased amount of mucus secreted under stress due to ATZ exposure. Under such conditions, the efficiency of oxygen uptake decreased considerably, which was manifested as enhanced breathing rate along with more frequent visits to surface water for gulping fresh air. Such altered behavior has not been exhibited by fish from the control group, which indicated that ATZ was responsible for such changes. Likely, different behavioral changes in common carp were observed after exposure to different concentrations of ATZ (Bahlova et al. 2014). Chapadense et al. (2009) recorded different behavioral changes in Colossoma macropommum after exposure to ATZ such as lethargy, increased frequency of opercular movements, and equilibrium loss. Fish would have shown this altered behaviour due to different internal biochemical and physiological changes in coping with the stress induced by the pesticides. These alterations may take place to compensate for the challenge posed by pesticides.

To evaluate these lethal, chronic, acute, or toxic effects, different biochemical and physiological parameters are appraised, such as endocrine disruption, the concentration of cortisol, blood glucose, ACh or AChE, protein contents, metabolic enzymes and activities of antioxidant enzymes in different tissues. Proteins are one of the fundamental biochemical properties used to describe the general health of fish and the mechanism of metabolism under pollutant stress (Martinez et al. 2004). In the present study, ATZ caused a significant time dependant decrease in total protein contents of the liver, brain, gills, and muscle tissue of Silver carp. The decrease in protein levels is due to the stress immobilization of these 
compounds in response to the increased energy required by fish to cope with toxic environmental conditions (Vasanthi et al. 1990). Therefore, a decrease in protein concentrations was observed compared to the control group, which might be due to the conversion of protein to glucose by the process of gluconeogenesis to cope with the stress induced by ATZ. This result was consistent with Ramesh et al. (2008); Ramesh et al. (2009) and Khan et al. (2016).

It is well established that exposure to xenobiotics leads to increased production of ROS (Ullah et al. 2019b). The results of this study showed that, like other animals, fish suffered from oxidative stress and responded by altering the activity of antioxidant enzymes. Jin et al. (2010) observed that exposure to ATZ led to oxidative stress in zebrafish, which is in agreement with our study as revealed by an increase in the lipid peroxidation. Every organism has a unique enzyme system to overcome this problem, which shows variations in its activities by facing ROS (Shao et al. 2012). In fish like other vertebrates' catalase is the most important enzyme which reduces hydrogen peroxide $\left(\mathrm{H}_{2} \mathrm{O}_{2}\right)$ to water and oxygen. CAT not only neutralizes the directly produced $\mathrm{H}_{2} \mathrm{O}_{2}$ but also neutralizes the $\mathrm{H}_{2} \mathrm{O}_{2}$ produced after the neutralization of superoxide anion by SOD (Hermes-Lima 2004). The fluctuation in the activity of CAT across the tissues studied revealed its primary role in the antioxidant defense system and its susceptibility to ATZ. CAT detoxifies $\mathrm{H}_{2} \mathrm{O}_{2}$ to water.

Glutathione reductase is an important antioxidant enzyme that plays important role in reducing oxidative stress in aquatic animals (Hasspier et al. 1994; Gohar et al. 1999). Peroxidase catalyzes both $\mathrm{H}_{2} \mathrm{O}_{2}$ and hydroxyl radicals into oxygen and water while glutathione reductase catalyzes NADPH-dependent regeneration of glutathione (GSH) from the oxidized form glutathione disulfide (GSSG) generated by peroxidase. Therefore, the elevation in the activities of the antioxidant enzymes reveals the compensatory responses of the exposed species against the induced stress after exposure to toxicants, such as ATZ in our study. Sometimes, the decreased activities of these antioxidants reveal that the exposed organisms suffered from damage after exposure, exhausted, and consequently, their antioxidant enzymes system got weaken such as Santos and Martinez (2012) observed reduced activities of GPx, CAT, and SOD in the liver of Prochilodus lineatus after exposure to ATZ. Hence, antioxidant enzymes provide the first line of defence against stress (Ullah et al. 2014).

The antioxidant enzymes including CAT, POD, and GR protect against oxidative stress by converting reactive oxygen intermediates to non-radical products. The current result showed that fish like other animals, undergo oxidative stress, and responded by changing the activity of antioxidant enzymes (Montilla et al. 1998). The present study revealed that Atrazine exposure causes a significant decrease in the activity of CAT in the liver, gills, brain, and muscle tissue exposed to ATZ 8, ATZ10, ATZ13, and ATZ15 for $24,48,72$, and 96 hours. The CAT activity increased slightly from 24 to $96 \mathrm{~h}$ in the control group whereas decreased in the ATZ treated group. The reason for the decrease in catalase activity may be the inactivation of the enzyme by the overproduction of ROS (Pigeolet et al. 1990). Xing et al. (2012) observed a decrease in CAT activity after exposure of common carp to ATZ, however, Nwani et al. (2010) observed an increase in the activity of CAT in Channa punctatus after exposure to ATZ. POD activity in the ATZ treated group was also decreased from 24 to $96 \mathrm{~h}$ compared to the control group where it 
increases over time. This finding is consistent with that of Santos et al. (2012) where a decreasing trend of antioxidant enzymes was observed in $P$. lineatus exposed to Atrazine. The increased activity of GR, in treated groups, indicates an attempt to maintain normal levels of glutathione. The maintenance of

glutathione might contribute to the reduction of atrazine toxicity through its association with the herbicide molecule (Wiegand et al. 2001). This is supported by Elia et al. (2002) who reported increased GR activity in the muscle and liver tissues of bluegill sunfish (Lepomis macrochirus) following exposure to atrazine.

Lipid peroxidation is a complex process that is more active in bio-membranes rich in polyunsaturated fatty acids. Reactive oxygen species (ROS) produced during oxidative stress react with unsaturated fatty acids present in the membrane and cause lipid peroxidation (Thiele et al. 1995). The estimation of LPO provides useful data about the effect of exposure to aquatic pollutants. After exposure to toxic substances, several researchers have reported increased levels of LPO in various fish tissues (Uner et al. 2001). Therefore, the result of this study indicated that administration of ATZ increased MDA levels in the liver, gill, brain, and muscle of the treated group as compared to the control group, which adversely impact the biological integrity of the exposed individuals. This finding is consistent with Elia et al. (2002). Xing et al., (2012) observed a concentration-dependent increase in MDA level in the kidney and brain of common carp. Increased lipid peroxidation level is an indicator of elevated ROS levels and consequently reveals the initiation of damage to the cellular membrane. Hence, LPO is a valuable biomarker and is extensively used to research oxidative stress.

\section{Conclusion}

This study concluded that Atrazine is toxic to Silver carp. Its exposure induced oxidative stress and led to alterations in the activities of antioxidant enzymes, protein content, and lipid peroxidation level in the liver, brain, gills, and muscle tissues. The results of the current study can be interpolated on other fish species as well. The study further recommend that pesticides used on farmland not only control target organisms rather affect other non-target organisms that can also pose a risk to human health.

\section{Declarations}

\section{Ethics approval and consent to participate}

The study was approved by the Ethical Committee of KUST, Kohat. Consent for participation was taken from the owners/participants of animals.

\section{Consent for publication}

Not Applicable

\section{Availability of data and materials}


The datasets used/or analyzed during the current study are available from the corresponding author on reasonable request.

\section{Competing interests}

None.

\section{Funding}

The study was supported by the SRGP project No. 1894 of the Higher Education Commission of Pakistan.

\section{Authors' contributions}

Study plan: FUD, NN, and SAURS. Manuscript preparation: NN, SAURS, and SU. Lab work: NN, SAURS, and SA. Data analysis: FUD, NN, MR, and AA. Critical evaluation and prepared final draft: SNK, AA, SU, and FUD. All authors approved the final draft of the manuscript.

\section{References}

Abarikwu, S.O., \& Farombi, E.O. (2016). Quercetin ameliorates atrazine-induced changes in the testicular functions of rats. Toxicology and Industrial Health, 32(7), 1278-1285.

Al-Sabti, K., \& Metcalfe, C. D. (1995). Fish micronuclei for assessing genotoxicity in water. Mutation Research/Genetic Toxicology, 343(2-3), 121-135.

Blahová, J., Plhalová, L., Hostovský, M., Divišová, L., Dobšíková, R., Mikulíková, I., . . S Svobodová, Z. (2013). Oxidative stress responses in zebrafish Danio rerio after subchronic exposure to atrazine. Food and chemical toxicology, 61, 82-85.

Bahlova, J., Modra, H., Sevcikova, M., Marsalek, P., Zelnickova, L., Skoric, M., \& Svobodova, Z. (2014). Evaluation of biochemical, haematological, and histopathological responses and recovery ability of common carp (Cyprinus carpio L.) after acute exposure to atrazine herbicide. BioMed Research International, 2014, 980948.

Chapadense, P.F.G., Castro, F.D.J., Almeida, J.A., \& Moron, S.E. (2009). Toxicity of atrazine herbicide in Colossoma macropomum. Revista Brasileira de Saude e Producao Animal, 10, 398-405.

Cheng, M., Zeng, G., Huang, D., Lai, C., Xu, P., Zhang, C., . . Zhu, Y. (2016). Degradation of atrazine by a novel Fenton-like process and assessment the influence on the treated soil. Journal of Hazardous Materials, 312, 184-191.

Carlberg, I., \& Mannervik, B. (1975). Purification and characterization of the flavoenzyme glutathione reductase from rat liver. Journal of biological chemistry, 250(14), 5475-5480.

Chance, B., \& Maehly, A. (1955). [136] Assay of catalases and peroxidases. 
Cui, H., Hwang, H.-M., Zeng, K., Glover, H., Yu, H., \& Liu, Y. (2002). Riboflavin-photosensitized degradation of atrazine in a freshwater environment. Chemosphere, 47(9), 991-999.

Davis, R.K., Pederson, D.T., Blum, D.A., \& Carr, J.D. (2007). Atrazine in a stream-aquifer system: estimation of aquifer properties from atrazine concentration profiles. Ground Water Monitoring and Remediation, 13 (2), 134-141.

Dawar, F. U., Zuberi, A., Azizullah, A., \& Khattak, M. N. K. (2016). Effects of cypermethrin on survival, morphological and biochemical aspects of rohu (Labeo rohita) during early development. Chemosphere, $144,697-705$.

Dornelles, M.F., \& Oliveira, G.T. (2014) Effect of atrazine, glyphosate and quinclorac on biochemical parameters, lipid peroxidation and survival in bullfrog tadpoles (Lithobates catesbeianus). Archives in Environmental Contamination and Toxicology, 66(3), 415-429.

El-Gohary, M., Awara, W. M., Nassar, S., \& Hawas, S. (1999). Deltamethrin-induced testicular apoptosis in rats: the protective effect of nitric oxide synthase inhibitor. Toxicology, 132(1), 1-8.

Elia, A., Waller, W., \& Norton, S. (2002). Biochemical responses of bluegill sunfish (Lepomis macrochirus, Rafinesque) to atrazine induced oxidative stress. Bulletin of environmental contamination and toxicology, 68(6), 809-816.

Elia, A., Waller, W., \& Norton, S. (2002). Biochemical responses of bluegill sunfish (Lepomis macrochirus, Rafinesque) to atrazine induced oxidative stress. Bulletin of Environmental Contamination and Toxicology, 68(6), 809-816.

Fisheries, F. (2012). Aquaculture Department. The state of world fisheries and aquaculture, 1-153.

Gely-Pernot, A., Saci, S., Kernanec, P-Y., Hao, C., Giton, F., Kervarrec, C., Tevosian, S., Mazaud-Guittot S., \& Smagulova, F. (2017). Embryonic exposure to the widely-used herbicide atrazine disrupts meiosis and normal follicle formation in femal mice. Scientific Reports, 7, 3526.

Glæsner, N., Bælum, J., Strobel, B.W., \& Jacobsen, C.S. (2014) Ageing of atrazine in manure amended soils assessed by bioavailability to Pseudomonas sp. strain ADP. Biodegradation, 25(2):217-225.

Hasspieler, B. M., Behar, J. V., \& Digiulio, R. T. (1994). Glutathione-dependent defense in channel catfish (Ictalurus punctatus) and brown bullhead (Ameriurus nebulosus). Ecotoxicology and Environmental Safety, 28(1), 82-90.

Hermes-Lima, M., 2004. Oxygen in biology and biochemistry: role of free radicals. In: Storey, K.B. (Ed.), Functional Metabolism: Regulation and Adaptation. John Wiley \& Sons, New York, pp. 319-368.

Huang, H., Zhang, S., Wu, N., Luo, L., \& Christie, P. (2009) Influence of Glomus etunicatum/Zea mays mycorrhiza on atrazine degradation, soil phosphatase and dehydrogenase activities, and soil microbial 
community structure. Soil Biol Biochem, 41(4):726-734.

Hussain, R., Mahmood, F., Khan, M.Z., Khan, A., \& Muhammad, F. (2011). Pathological and genotoxic effects of atrazine in male Japanes quail (Coturnix japonica). Ecotoxicology, 20, 1-8.

Jin, Y., Zhang, X., Shu, L., Chen, L., Sun, L., Qian, H., Liu, W., \& Fu, Z. 2010. Oxidative stress response and gene expression with atrazine exposure in adult female zebrafish (Danio rerio), Chemosphere, 78, 846852.

Khalil, S. R., Reda, R. M., \& Awad, A. (2017). Efficacy of Spirulina platensis diet supplements on disease resistance and immune-related gene expression in Cyprinus carpio L. exposed to herbicide atrazine. Fish \& Shellfish Immunology, 67, 119-128.

Khan, A., Shah, N., Muhammad, M., Khan, M. S., Ahmad, M. S., Farooq, M., .. Yousafzai, A. M. (2016). Quantitative determination of lethal concentration LC 50 of atrazine on biochemical parameters; total protein and serum albumin of freshwater fish grass carp (Ctenopharyngodon idella). Polish Journal of Environmental Studies, 25(4), 1555-1561.

Khoshnood, Z., Jamili, Sh., Khodabandeh, S., Maschinchian, M.A., Motallebi, M.A.A. (2014). Histopathological effects and toxicity of atrazine herbicide in Caspian Kutum, Rutilus frisii kutum, fry. Iranian Journal of Fisheries Sciences, 13(3), 702-718.

Kumar, A., Sharma, B., \& Pandey, R. S. (2007). Preliminary evaluation of the acute toxicity of cypermethrin and $\lambda$-cyhalothrin to Channa punctatus. Bulletin of Environmental Contamination and Toxicology, 79(6), 613-616.

Kumar, V., Upadhyay, N., Singh, S., Singh, J., \& Kaur, P. (2013). Thin-layer chromatography: comparative estimation of soil's atrazine. Current World Environment, 8(3), 469.

Kreutz, L.C., Barcellos, L.J.G., dos Santos, E, D., Pivato, M., \& Zanatta, R. (2012). Innat immune response of silver catfish (Rhamdia quelen) exposed to atrazine. Fish and Shellfish Immunology, 33, 1055-1059.

Lazhar, M., Hela, T., Moncef, B., \& Neji, A. 2012. Toxicity of three selected pesticides (Alachlor, Atrazine and Diuron) to the marine fish (turbot Psetta maxima). African Journal of Biotechnology, 11(51), 1132111328.

Li, G., Sinclair, A. J., \& Li, D. (2011). Comparison of lipid content and fatty acid composition in the edible meat of wild and cultured freshwater and marine fish and shrimps from China. Journal of agricultural and food chemistry, 59(5), 1871-1881.

Lowry, O. H., Rosebrough, N. J., Farr, A. L., \& Randall, R. J. (1951). Protein measurement with the Folin phenol reagent. Journal of biological chemistry, 193, 265-275. 
Martinez, C., Nagae, M., Zaia, C., \& Zaia, D. (2004). Acute morphological and physiological effects of lead in the neotropical fish Prochilodus lineatus. Brazilian Journal of Biology, 64(4), 797-807.

Mhadhbi, L. \& Beiras, R. (2012). Acute toxicity of seven selected pesticides (Alachlor, Atrazine, Dieldrin, Diuron, Pirimphos-Methyl, Chlorpyrifos, Diazinon) to the marine fish (Turbot, Psetta maxima). Water Air and Soil Pollution, 223, 5917-5930.

Montilla, P. L., Vargas, J. F., Túnez, I. F., Carmen, M., de Agueda, M., Valdelvira, M. E. D., \& Cabrera, E. S. (1998). Oxidative stress in diabetic rats induced by streptozotocin: protective effects of melatonin. Journal of pineal research, 25(2), 94-100.

Moore, A., \& Lower, N. (2001). The impact of two pesticides on olfactorymediated endocrine function in mature male Atlantic salmon (Salmosalar L.) parr [J]. Comparative Biochemistry Physiology Part B, 129, 269-276.

Nwani, C.D., Lakra, W.S., Nagpure, N.S., Kumar, R., Kushwaha, B., \& Srivastava, S.K. 2010. Toxicity of the herbicide atrazine: effects on lipid peroxidation and activities of antioxidant enzymes in the freshwater fish Channa punctatus (Bloch). International Jorunal of Environmental Research and Public Health, 7, 3298-3312.

Pandey, A., George, K., \& Peer Mohamed, M. (1995). Effect of DDT on thyroid gland of the mullet Liza parsia (Hamilton-Buchanan). Journal of the Marine Biological Association of India, 37(1\&2), 287-290.

Pigeolet, E., Corbisier, P., Houbion, A., Lambert, D., Michiels, C., Raes, M., . . Remacle, J. (1990). Glutathione peroxidase, superoxide dismutase, and catalase inactivation by peroxides and oxygen derived free radicals. Mechanisms of ageing and development, 51(3), 283-297.

Ramesh, M., \& Saravanan, M. (2008). Haematological and biochemical responses in a freshwater fish Cyprinus carpio exposed to chlorpyrifos. International journal of integrative biology, 3(1), 80-83.

Ramesh, M., Srinivasan, R., \& Saravanan, M. 2009. Effect of atrazine (herbicide) on blood parameters of common carp Cyprinus carpio (Actinopterygii: Cypriniformes). African Journal of Environmental Science and Technology, 3(12), 453-458.

Santos, T. G., \& Martinez, C. B. (2012). Atrazine promotes biochemical changes and DNA damage in a Neotropical fish species. Chemosphere, 89(9), 1118-1125.

Shelley, L. K., Ross, P. S., Miller, K. M., Kaukinen, K. H., \& Kennedy, C. J. (2012). Toxicity of atrazine and nonylphenol in juvenile rainbow trout (Oncorhynchus mykiss): Effects on general health, disease susceptibility and gene expression. Aquatic toxicology, 124, 217-226.

Singh, M., Kaur, P., Sandhir, R., \& Kiran, R. (2008). Protective effects of vitamin E against atrazine-induced genotoxicity in rats. Mutation Research/Genetic Toxicology and Environmental Mutagenesis, 654(2), 145149. 
Singh, M., Sandhir, R., \& Kiran, R. (2011). Effects on antioxidant status of liver following atrazine exposure and its attenuation by vitamin E. Experimental and Toxicologic Pathology, 63(3), 269-276.

Singh, S., Kumar, V., Chauhan, A., Datta, S., Wani, A.B., Singh, N., \& Singh, J. (2018). Toxicity, degradation and analysis of the herbicide atrazine. Environmental Chemistry Letters, 16, 211-237.

Shao, B., Zhu, L., Dong, M., Wang, J., Wang, J., Xie, H., . . Zhu, S. (2012). DNA damage and oxidative stress induced by endosulfan exposure in zebrafish (Danio rerio). Ecotoxicology, 21(5), 1533-1540.

Song, Y., Jia, Z.C., Chen, Y.J., Hu, J.X., Zhang, L.S. (2014). Toxic effects of atrazine on reproductive system of male rats. Biomedical and Environmnetal Sciences, 74(4), 281-288.

Thiele, J., Freisleben, H., Fuchs, J., \& Ochsendorf, F. (1995). Ascorbic acid and urate in human seminal plasma: determination and interrelationships with chemiluminescence in washed semen. Human Reproduction, 10(1), 110-115.

Tomlin C. (2000). The pesticide Manual: a world compendium. $12^{\text {th }}$ ed. Farnham (UK): The British Crop Protection Council.

Ullah, S., \& Zorriehzahra, M. J. (2015). Ecotoxicology: a review of pesticides induced toxicity in fish. Advances in Animal and Veterinary Sciences, 3(1), 40-57.

Ullah, S., Li, Z., Arifeen, M.Z.U., Khan, S.I., \& Fahad, S. (2019b). Multiple biomarkers based appraisal of deltamethrin induced toxicity in silver carp (Hypophthalmichthys molitrix). Chemosphere, 214, 519-533.

Ullah, S., Li, Z., Zuberi, A., Arifeen, M.Z.U., \& Baig, M.M.F.A. (2019a). Biomarkers of pyrethroid toxicity in fish. Environmental Chemistry Letters, 17, 945-973.

Ullah, S., Zuberi, A., Alagawany, M., Farag, M.R., Dadar, M., Karthik, K., Tiwari, R., Dhama, K., \& Iqbal, H.M.N. (2018). Cypermethrin induced toxicities in fish and adverse health outcomes: Its prevention and control measure adaptation. Journal of Environmental Management, 206, 863-871.

Üner, N., Oruç, E. Ö., Canli, M., \& Sevgler, Y. (2001). Effects of cypermethrin on antioxidant enzyme activities and lipid peroxidation in liver and kidney of the freshwater fish, Oreochromis niloticus and Cyprinus carpio (L.). Bulletin of Environmental Contamination and Toxicology, 67(5), 657-664.

USEPA (2001). Revised preliminary human health risk assessment atrazine-registration branch 3. office of Pesticide Programs, Health Effects Division.

United States Environmental Protection Agency, April, (2006). Decision Documents for Atrazine. Washington D.C.

Ullah, R., Zuberi, A., Ullah, S., Ullah, I., \& Dawar, F. U. (2014). Cypermethrin induced behavioral and biochemical changes in mahseer, Tor putitora. The Journal of toxicological sciences, 39(6), 829-836. 
Vasanthi, R., Baskaran, P., \& Palanichamy, S. (1990). Influence of carbofuron on growth and protein conversion efficiency in some freshwater fishes. Journal of Ecobiology, 2(1), 85-88.

Vonberg, D., Vanderborght, J., Cremer, N., Putz, T., Herbst, M., \& Vereecken, H. (2014) 20 years of long-term atrazine monitoring in a shallow aquifer in western Germany. Water Research, 50, 294-306.

Wiegand, C., Krause, E., Steinberg, C., \& Pflugmacher, S. (2001). Toxicokinetics of atrazine in embryos of the zebrafish (Danio rerio). Ecotoxicology and environmental safety, 49(3), 199-205.

Wightwick, A., \& Allinson, G. (2007). Pesticide residues in Victorian waterways: a review. Australasian Journal of Ecotoxicology, 13(3), 91.

Wright, J., Colby, H., \& Miles, P. (1981). Cytosolic factors which affect microsomal lipid peroxidation in lung and liver. Archives of Biochemistry and Biophysics, 206(2), 296-304.Waring, C. P., \& Moore, A. (2004). The effect of atrazine on Atlantic salmon (Salmo salar) smolts in fresh water and after sea water transfer. Aquatic toxicology, 66(1), 93-104.

Xing, H.J., Han, Y., Li, S., Wang, J., Wang, X., \& Xu, S. (2010). Alterations in mRNA expression of acetylcholinesterase in brain and muscle of common carp exposed to atrazine and chlorpyrifos [J]. Ecotoxicology and Environmental Safety, 72(7): 1666-1670.

Xing, H., Li, S., Wang, Z., Gao, X., Xu, S., Wang, X. 2012. Histopathological changes and antioxidant response in brain and kidney of common carp exposed to atrzine and chlorpyrifos. Chemosphere, 88 , 377-383.

Xing, H., Liu, T., Zhang, Z., Wang, X., \& Xu, S. 2015. Acute and subchronic toxic effects of atrazine and chlorpyrifos on common carp (Cyprinus carpio L.): Immunotoxicity assessments. Fish \& Shellfish Immunology, 45(2), 327-333.

Zadeh AK, Sohrab AD, Alishahi M, Khazaei SH, Asgari HM (2016) Evaluation of acute and sub-lethal toxicity of herbicide, atrazine, on hematological parameters of Tor grypus. Journal of Veterinary Research, 71(3), 295-301

Zhang, X., Wang, M., Gao, S., Ren, R., Zheng, J. \& Zhang, Y. (2011). Atrazine-induced apoptosis of splenocytes in BALB/C mice. BMC Medicine, 9, 117.

\section{Figures}




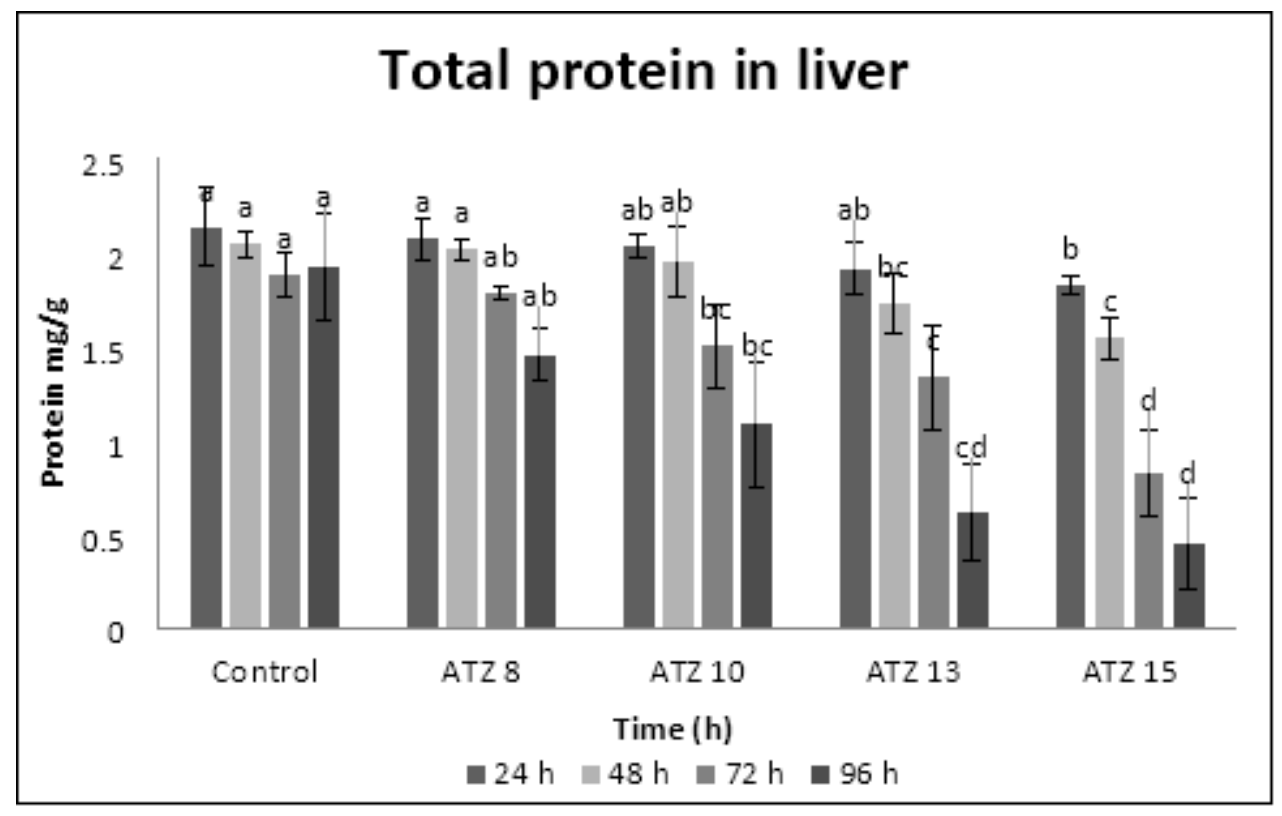

Figure 1

Total protein content in liver of Silver carp exposed to ATZ. The data are expressed as mean \pm S.E and analyzed by ANOVA $(P<0.05)$

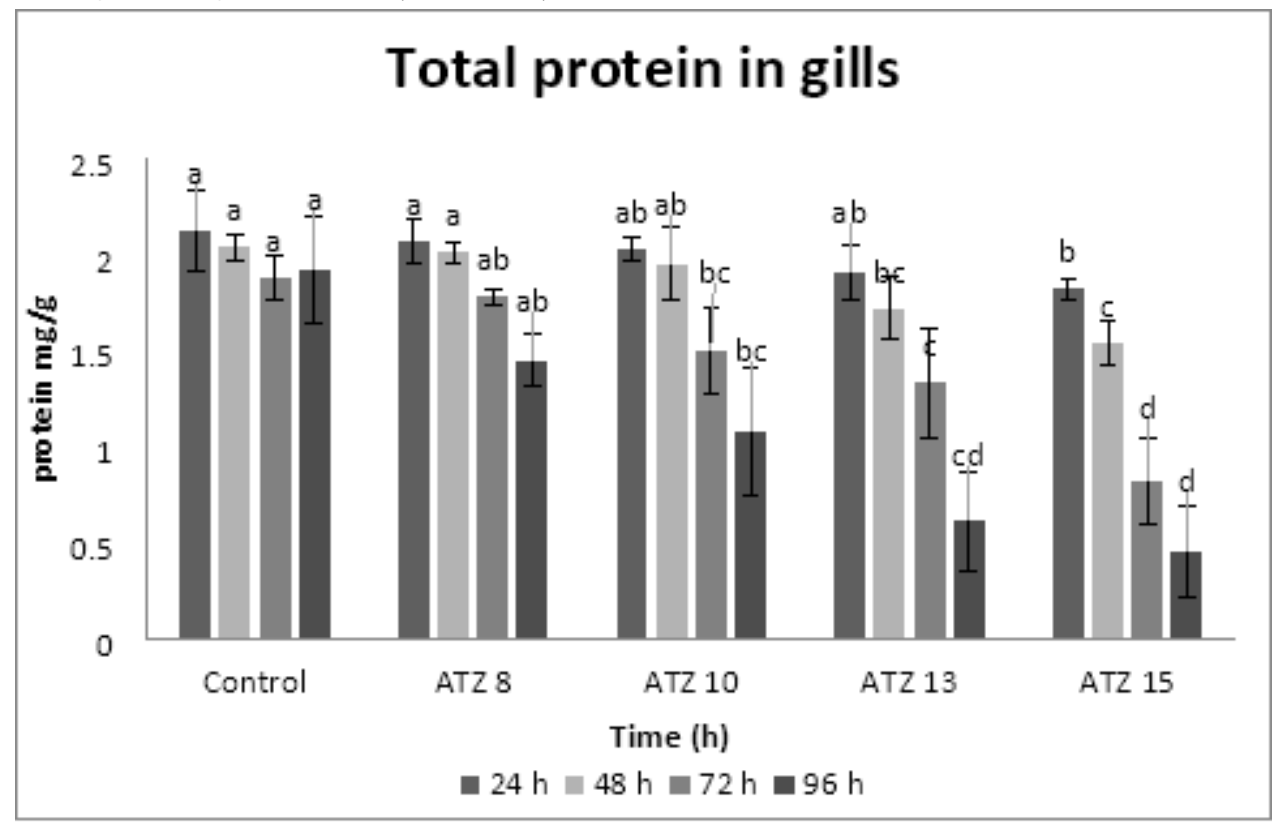

Figure 2

Total protein content in gills of Silver carp exposed to ATZ. The data are expressed as mean \pm S.E and analyzed by ANOVA $(P<0.05)$ 


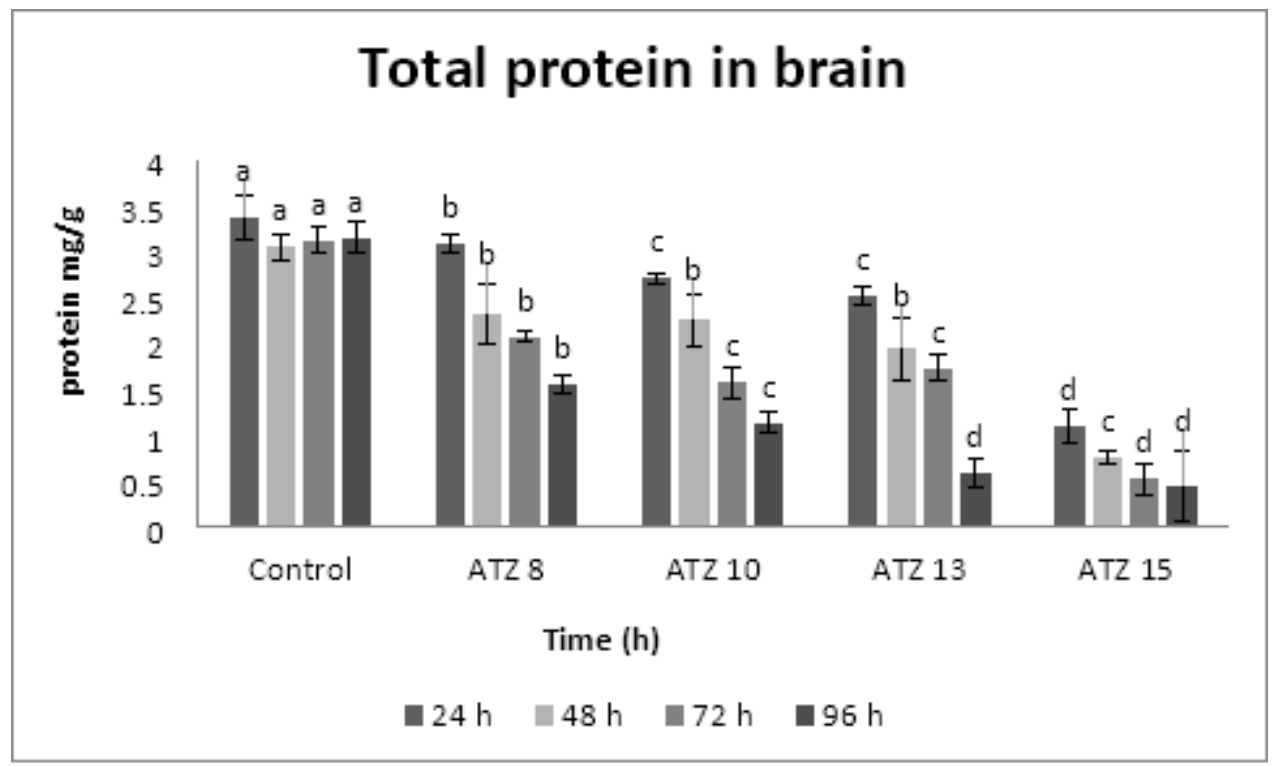

Figure 3

Total protein content in the brain of Silver carp exposed to ATZ. The data are expressed as mean \pm S.E and analysed by ANOVA $(P<0.05)$

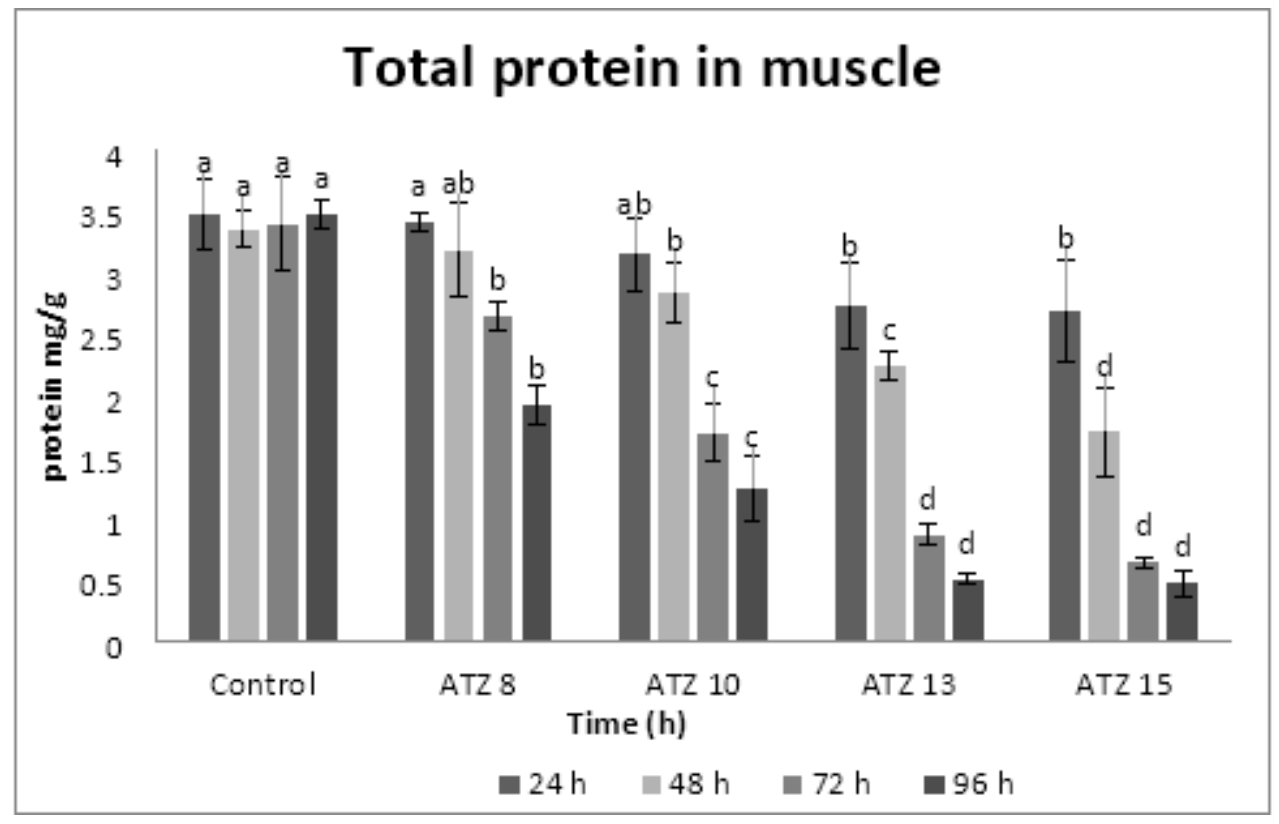

Figure 4

Total protein content in muscle of Silver carp exposed to ATZ. The data are expressed as mean \pm S.E and analysed by ANOVA $(P<0.05)$ 


\section{LPO in liver}

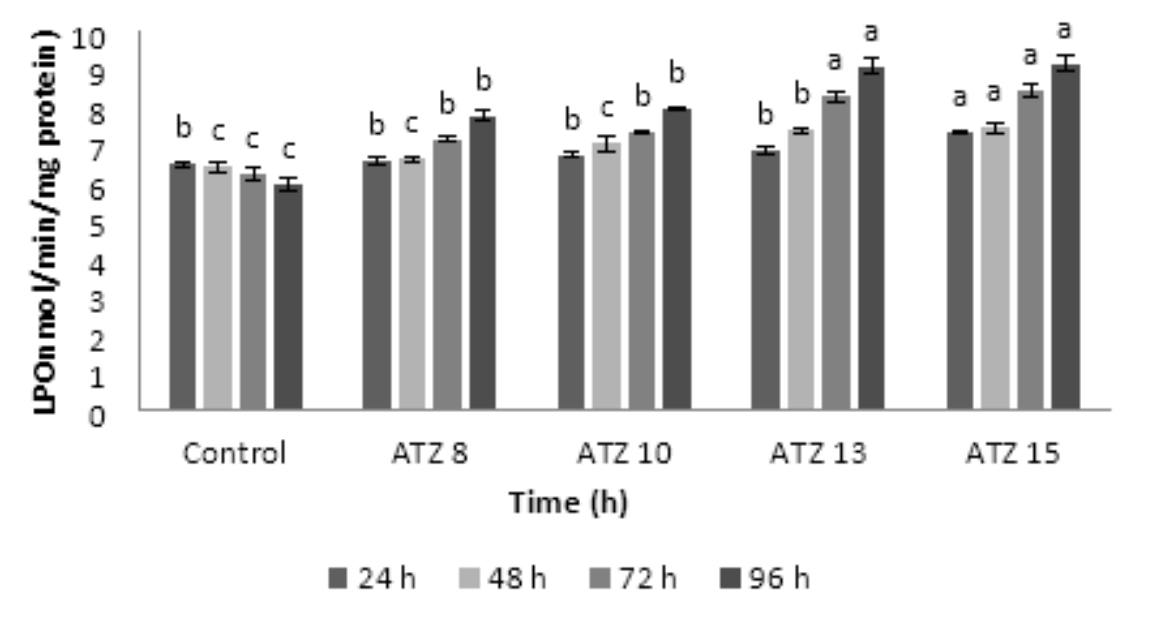

Figure 5

Effect of Atrazine on lipid peroxidation in liver of Silver carp. The data are expressed as mean $\pm S$. $E$ and analysed by ANOVA $(P<0.05)$

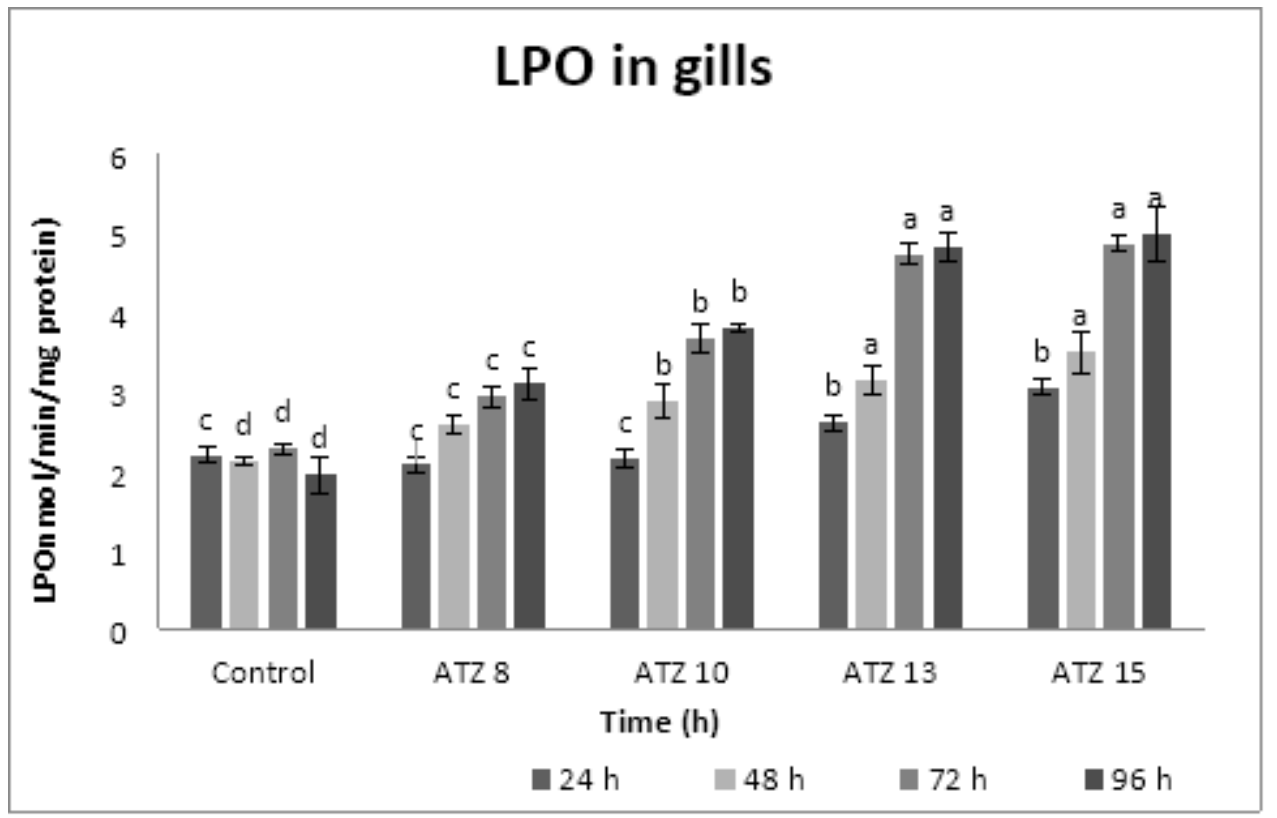

Figure 6

Effect of Atrazine on lipid peroxidation in gills of Silver carp. The data are expressed as mean \pm S.E and analysed by ANOVA $(P<0.05)$ 


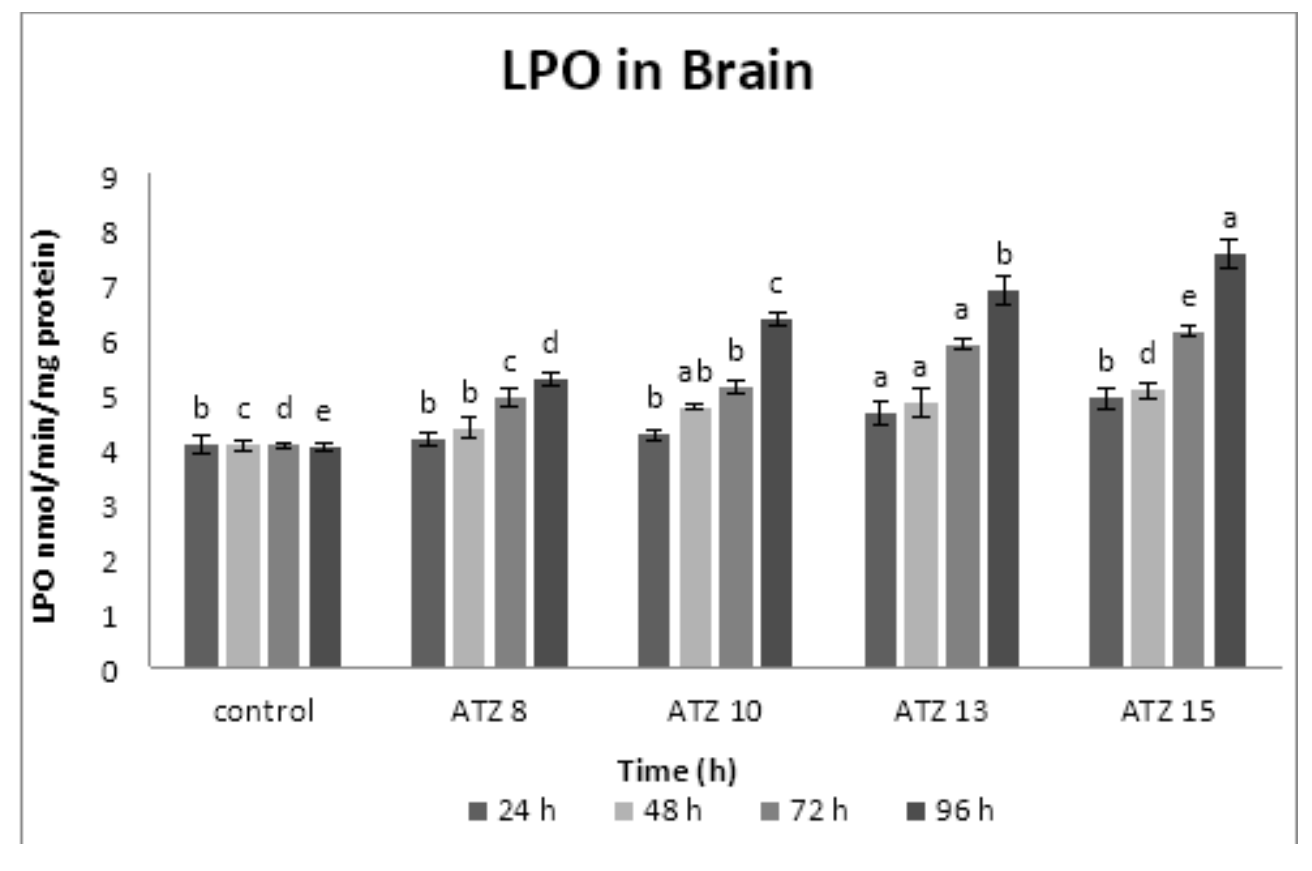

Figure 7

Effect of Atrazine on lipid peroxidation in the brain of Silver carp. The data are expressed as mean \pm S.E and analysed by ANOVA $(P<0.05)$

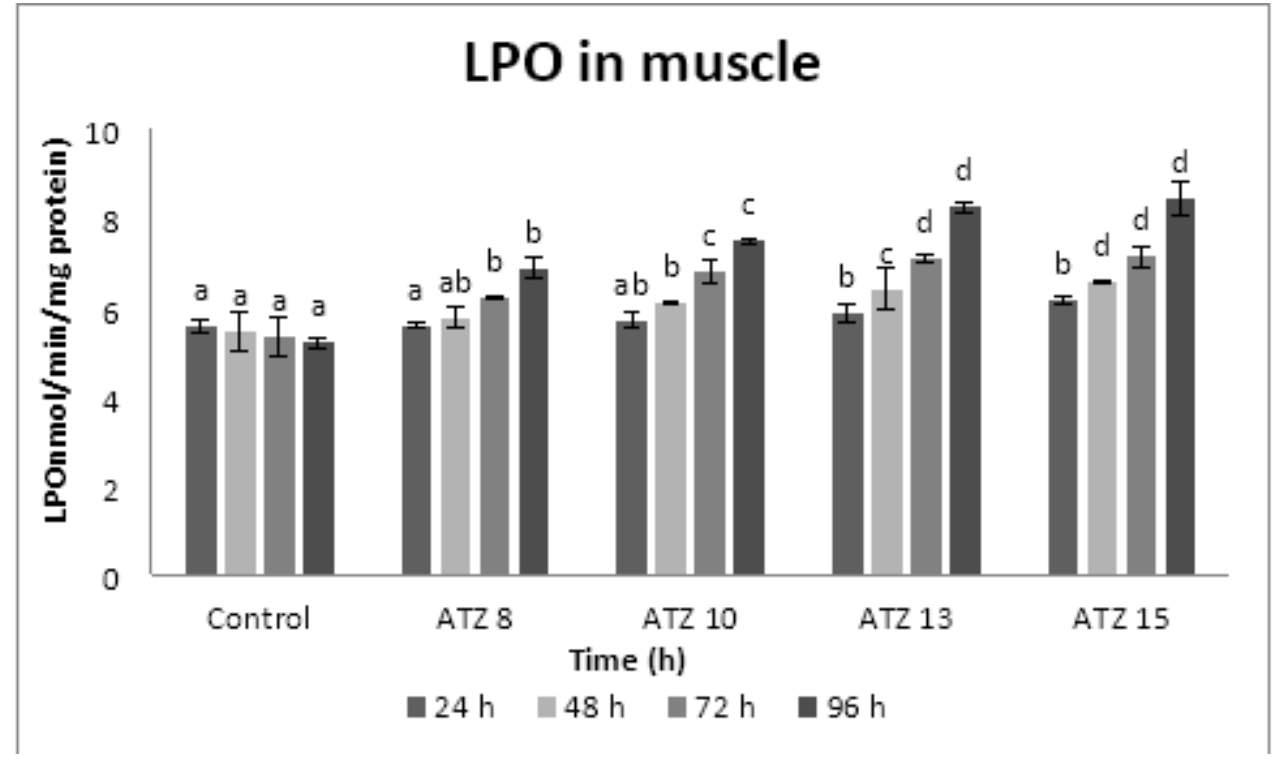

Figure 8

Effect of Atrazine on lipid peroxidation in the muscle of Silver carp. The data are expressed as mean \pm S.E and analysed by ANOVA $(P<0.05)$ 